\title{
Chapter 7 \\ Evaluation of the Policy of Crop \\ Diversification as a Strategy for Reduction of Rural Poverty in India
}

\author{
Aparajita Mukherjee
}

\begin{abstract}
This paper examines the effectiveness of crop diversification in ensuring greater availability of food and nutrition to the Indian cultivators, under varied irrigation and infrastructure conditions. We undertake empirical investigation with primary farm-level data into the extent and severity of poverty and food deprivation among very marginal, marginal and small farmers, practicing crop diversification to different degrees, in three districts of an Indian province. The viability of the strategy is also examined by comparing farm-level efficiency and profitability of high-value crops vis-à-vis traditional crops. By and large, our test results indicate an inverse association between the extent of crop diversification and calorie intake per capita across the regions. In areas suffering from adverse soil and other characteristics which make it difficult to develop irrigation, farmers are compelled to diversify away from water-intensive traditional crops to ensure a minimum acceptable level of consumption, but they still find it hard to avoid poverty and malnutrition. By contrast, in places where the farmers develop access to irrigation through private investment, crop diversification enables them to maintain some reasonable level of consumption and positive net income. But high-value crop production results in low profitability and relative inefficiency. The study indicates the need for a more direct policy intervention to ensure effectiveness of crop diversification as a strategy for reduction of rural poverty in India.
\end{abstract}

Keywords Crop diversification - Marginal and very marginal farmers - Irrigation and infrastructure - Poverty and malnutrition - Efficiency and profitability

\footnotetext{
A. Mukherjee $(\bowtie)$

Visva-Bharati University, Santiniketan, India

e-mail: apmmuk.snt@gmail.com
} 


\subsection{Introduction}

According to World Bank's estimate for 2010, India has the largest number of the poor in the world, comprising one-third of the world's poor (World Bank 2010). ${ }^{1}$ Notwithstanding the fact that the method of estimating poverty is fraught with confusion and controversies (Himangsu 2008; Patnaik 2010; Raphelle 2013; Gangopadhyay and Singh 2013), and different procedures for estimation of poverty are followed by different agencies such as the World Bank, the Asian Development Bank, and others, estimated figures of absolute poverty and poverty ratio indicate that in India, poverty is still quite high, though there is a falling trend in the poverty ratio (Himangsu 2008). Further, Indian researchers observe a divergence between poverty measures based on real expenditure and those based on direct calorie requirement. Estimates of the proportion of the population not getting adequate calorie are even higher than the estimated figures of poverty ratio (Himangsu 2008; Deaton and Dreze 2009; Patnaik 2010).

The agricultural sector in India, being dominated by very marginal, marginal and small farmers, faces the problem of low productivity, low availability of food grains and low income (Desai et al. 2011), leading to a high level of poverty, particularly in areas with extremely backward infrastructure and irrigation systems. While during 1992-1993 to 1996-1997, the average annual compound growth of the yield rate of food grains was 2.05, it was 1.23 during 1997-1998 to 2001-2002 and came down to 1.09 during 2002-2005 to 2005-2006. ${ }^{2}$ Wheat and coarse cereals also experienced a similar trend, with wheat experiencing a negative rate of growth during the last phase. As a result, the average annual compound growth rate of food grain production, which was 3.22 in the 1950s, came down to 1.66 in the 1990 s. This led to an absolute decline in the per capita net availability of cereals and food grains from 468 and $510 \mathrm{~g}$ per day per head in 1991 to 422 and $454 \mathrm{~g}$ in 2000, to 407 and $444 \mathrm{~g}$ in 2009, respectively. ${ }^{3}$ The chemical-based technology, which leads to degradation of the fertility of soil through overuse of chemical fertilizers combined with a water-intensive traditional crop-based cropping pattern, is alleged to have contributed to the continuously falling yield rates throughout the country, making traditional crop-based agriculture nonviable (Sing 2004; World Bank 2005). Based on observations of

\footnotetext{
${ }^{1}$ World Bank estimates Indian poverty at a head count ratio of $32.7 \%$ at $\$ 1.25$ per day as the poverty line income, the absolute figure being around 400 million, whereas world poverty is estimated at 1.2 billion. ADB, on the other hand, uses $\$ 1.35$ per day as the poverty line for India.

${ }^{2}$ We have estimated the average annual compound growth rates on the basis of data obtained from Agricultural Statistics at a Glance 2010, Directorate of Economics and Statistics, Department of Agriculture and Cooperation, Government of India (website: http://www.dacnet.nic.in/eands).

3 Agricultural Statistics at a Glance 2010, Directorate of Economics and Statistics, Department of Agriculture and Cooperation, Government of India (website: http://www.dacnet.nic.in/eands).
} 
the alleged failure of the traditional crop-based agriculture to face competition in the global market, diversification of the cropping pattern to high-value crops is suggested (World Bank 2005) as a major way out from the agrarian impasse. Our objective is to analyse situations under which such a transformation can be viable and serve as a strategy for reenergizing Indian agriculture, providing the farmers a way out from extreme vulnerability, and enabling them to avoid conditions of poverty and malnutrition.

This study is based on an empirical investigation with the use of primary data on different aspects of farming relating to 360 farming households belonging to different size classes of landholdings. We selected 6 administrative blocks of three districts in West Bengal, an Indian province, in order to consider varied conditions with regard to irrigation and infrastructure.

\subsection{A Brief Overview of Existing Literature and the Proposed Framework of Analysis}

We have not come across any study examining the relationship between crop diversification and poverty as such. Most studies, as we shall see below, observe the negative relationship between the extent of diversification, on the one hand, and farm size, and availability of irrigation and rainfall, on the other (Joshi et al. 2004; Singh and Sidhu 2004; Rao et al. 2006). This seems to indicate a direct relationship between crop diversification and small and marginal farmers' destitution due to lack of adequate water for cultivation. One of the observations the researchers arrive at is that diversification and production of labour-intensive high-value crops are taken up more by the small farmers than by the large farmers, to ensure bare subsistence by minimizing the risk of loss of livelihood associated with production of highly water-intensive traditional crops, particularly in areas suffering from acute problems relating to availability of irrigation (Joshi et al. 2004). The need to maintain a minimum level of income in the face of a high level of uncertainty, rather than profit consideration, induces the small farmers in less irrigated areas to undertake cultivation of horticultural crops side by side with cereals. A more disaggregated study using district-level data came to a similar observation that while existence of demand is a necessary condition for growth of high-value crops, high-value crops are more concentrated in districts with a higher concentration of small farmers (Rao et al. 2006).

In investigating the factors behind declining crop diversification in Punjab, some studies have observed that availability of greater irrigation facilities at cheap rates leads to specialization in one or two traditional crops, while lack of such facilities results in the adoption of diversification as a coping strategy (Singh and Sidhu 2004). In discussing agricultural crisis in India in the post-green revolution period, Sing (2004) also points out how diversification may help farmers to avert critical conditions. 
A study on Indian agriculture conducted by the World Bank (2005), however, arrives at a different view that increased diversification in the crop sector came about primarily 'to increase income rather than as a coping strategy to manage farm-level risk and uncertainty'. Diversification is observed to be the result of expansion of the market for high-value crops, greater access to markets and prospect of increased profitability in an open economy.

That increasing prospect of profits through expansion of market demand plays an important role in crop diversification had already been indicated by other researchers. It had been observed (Gulati and Batila 2001) that increased share of capital formation at the private and farm level in the face of a declining trend in public investment influenced the composition of agricultural production in favour of diversification away from food grain crops. As indicated, when falling public investment in irrigation induces the farmers to undertake private investment, they prefer to shift from cereal to non-cereal high-value crops.

Some researchers have shown there has been a substantial change in the composition of food (except for the lowest $30 \%$ of the income groups) both in rural and urban areas (Rao 2000), which serves as a factor inducing private investors to shift their investment initiative towards non-food grains (Gulati and Batila 2001). A study of the consumption pattern of 200 landless rural households in Tamil Nadu (Rajuladevi 2001), however, indicates abject poverty and extreme dependence on cereals as the main item of consumption. A study on the NSSO 59th round data also reveals changes in the consumption pattern except for the lowest stratum.

The studies discussed helped us to design the framework of the proposed study and develop the following propositions and hypotheses for empirical verifications. While lack of access to publicly supplied cheap irrigation is the single most important factor inducing crop diversification, crop diversification takes place under two alternative conditions: first, when it is possible to take initiative at the private level to develop farmers' access to irrigation; second, when it is not possible to develop irrigation by individual initiative because of extremely adverse natural conditions. In the first case, the farmers undertake diversification to ensure positive returns on their investment-expansion of market and other infrastructure play an inducing role in this case. We hypothesize that diversification may act as an effective strategy for reducing poverty among marginal and very marginal farmers under this situation. In the alternative situation, farmers take up diversification and production of high-value labour-intensive crops, using family labour, as a strategy for maintaining bare subsistence-in this situation, farmers find it hard to avoid poverty and malnutrition. We further hypothesize that small and marginal farmers in destitution choose to diversify towards production of high-value crops even if these are less viable from the point of view of efficiency and profitability. 


\subsection{The Methodology}

We use farm-level data collected on the basis of carefully designed ${ }^{4}$ samples of farming households through a field survey of six villages from three districts of West Bengal, an Indian province, to carry out our empirical investigation. The three districts selected from West Bengal are Hooghly, Burdwan and North 24 Parganas-each of these districts represents particular characteristics with regard to availability of irrigation. ${ }^{5}$ Burdwanis well endowed with public irrigation facilities, with almost $90 \%$ of its irrigated area under government canals and high soil fertility. Hooghly depends on a combination of public and private sources of irrigation, with less than $30 \%$ of its irrigated area under canals and deep tube wells. North 24 Parganas is not endowed with any public irrigation and infrastructure facilities in the most part and also suffers from high salinity of the soil, particularly in the southern part of the district. The districts are also different with respect to the cropping pattern. While Burdwan is mainly a traditional crop producing area, Hooghly produces both rice and potato, two traditional water-intensive crops, in substantial proportion, though some parts of the district produce vegetables and jute in considerable proportion. North 24 Parganas is famous as a producer and supplier of fruits and vegetables to urban areas surrounding the provincial capital Kolkata, which also serves as an outlet to the overseas market. Two separate administrative blocks were selected in each of these districts: one relatively more endowed with public irrigation and infrastructure, and the other with either less or none of these facilities. We selected villages/mouzas from each block representing the characteristics of the respective blocks with regard to irrigation and infrastructure, and constructed a sample of 60 farming households from the selected villages within each block following a stratified random sampling procedure so that four size classes $-<0.5$ ha (very marginal), 0.5 to $<1$ ha (marginal), $1<2$ ha (small) and $2<4$ ha (medium) — of agricultural holdings were represented proportionately in the population (the number of farms with more than 4 ha of farm size was negligible in the population). We kept the sample size at 60 for each of the blocks, with a total of 360 households from 6 blocks $(6 \times 60=360) .{ }^{6}$ Data on broad aspects of farming, including conditions with regard to irrigation and infrastructure, and consumption of different food items by the farmers were collected on the basis of structured questionnaires.

We measured the degree of crop diversification using Simpson's crop diversification index:

$\mathrm{CDI}=1-\sum\left(p_{i} / \sum p_{i}\right)^{2}$ where $p_{i}$ being the area under the $i$ th crop. The value of CDI lies between 0 and 1 , indicating complete specialization, when the value

\footnotetext{
4 The sample design is described in Appendix 1.

5 Data and information on availability of irrigation as well as cropping pattern of the districts are obtained from District Statistical Hand Book, Bureau of Applied Economics and Statistics, West Bengal.

${ }^{6}$ Details on the selection procedure are provided in Appendix 1.
} 
is 0 and extreme diversification when the value approximates 1 . Using CDI, we identified two groups of regions as 'more diversified' and 'less diversified'.

We estimated nutritional intakes of the farmers in both these regions on the basis of consumption data collected by us, using nutritional conversion rates as used by NSSO. ${ }^{7}$

To examine the viability of crop diversification in terms of its impact on relative farm-level efficiency, farm business income and profits per unit of investment, we estimated profitability under vegetables production and production of Aus, Aman and Boro. We undertook a comparative analysis of efficiency in the production of vegetables vis-à-vis these traditional crops using the non-parametric technique of Data Envelopment Analysis (DEA). ${ }^{8}$ However, since DEA does not measure efficiency in absolute terms, but relative to the best practice within the sample (its value lying between 0 and 1 , with 1 representing the best practice), the proportion of farms having a high DEA score and average DEA score of a category need to be considered by comparing the relative efficiency of different categories. ${ }^{9}$

In this paper, we restrict ourselves to comparing the overall technical efficiency (OTE) in input use between high-value crops and traditional crops using the DEA technique with the assumption of constant returns to scale with single crop models, instead of analysing scale efficiency and pure technical efficiency of a farm under the variable returns to scale assumption with a multi-crop model. This is because our major concern is to evaluate the effectiveness of crop diversification as a poverty alleviating strategy and compare the relative viability of high-value crops vis-à-vis traditional crops rather than the efficiency of a multi-crop farm. We also estimate profits on the basis of prices of output actually received and prices of inputs actually paid by farmers, and estimate farm business income by incorporating the imputed value of family labour and other owned inputs in the cost calculation.

Since both the ranges of CDI and efficiency scores obtained from DEA are censored, whenever we have conducted regression analysis with any of these two variables as the dependent variable, we have used the Tobit regression model.

\subsection{Results of Empirical Investigation}

\subsubsection{Extent of Crop Diversification in Relation to the Pattern and Extent of Irrigation}

The selected villages in our sample are endowed with different kinds of irrigation (publicly supplied cheap irrigation system vis-à-vis privately developed costly irrigation) to different degrees, are placed at different distances from cold storages,

\footnotetext{
7 Appendix 2 of NSSO Report No. 471(55/1.0/9).

${ }^{8}$ Detailed analysis of the technique is provided in Appendix 2.

9 Another major limitation of the DEA technique is that the results are too sensitive to not only measurement error, but also input and output specification and size of the sample.
} 
Table 7.1 Ranking of blocks and Simpson's crop diversification index (CDI)

\begin{tabular}{l|l|l|l|l}
\hline $\begin{array}{l}\text { Infrastructure } \\
\text { rank }\end{array}$ & Block & Irrigation code & CDI & CDI rank \\
\hline 1 & Pandua & 1 & 0.45 & 6 \\
\hline 2 & Memari & 1 & 0.49 & 5 \\
\hline 2 & Balagarh & 2 & 0.64 & 3 \\
\hline 5 & Bongaon & 3 & 0.67 & 2 \\
\hline 3 & Hasnabad & 6 & 0.68 & 1 \\
\hline 6 & Golsi & 2 & 0.55 & 4 \\
\hline
\end{tabular}

Source Field survey

markets, highways and railway stations, and are connected through different types of roads with these centres. Accordingly, we use a coding system to rank the survey villages in order of the extent and availability of irrigation from public and private sources and infrastructures, ${ }^{10}$ including distances from the marketing and storage centres, and type of link roads. We also estimate the crop diversification indices pertaining to the villages. Table 7.1 presents ranks of the blocks with regard to irrigation and infrastructure and the respective crop diversification indices.

The ranking of blocks shows that Memari and Pandua, the two least diversified blocks, fall in the same irrigation type with availability of publicly supplied cheap canal and deep tube well irrigation along with other sources. But the village in Pandua block placed in the best condition with regard to infrastructure is least diversified among the survey villages, followed by the village in Memari placed in the second best position with regard to infrastructure and second lowest position with regard to diversification. This confirms that when there is no lack of cheap publicly supplied water, farmers are induced to specialize in traditional crops, even in the presence of good infrastructure.

Villages under Balagar and Golsi, which depend on private and costly irrigation systems have an almost nonexistent public system of irrigation, enjoy the second position with regard to the extent of irrigation. While the much better position of Balagar with regard to infrastructure enables it to diversify its cropping pattern, the worst infrastructure condition in Galsi keeps it less diversified. This supports our proposition that when farmers develop access to irrigation at high private cost, they diversify the cropping pattern to ensure good returns, but extent of diversification depends on the availability of infrastructure in such cases.

Villages under North 24 Parganas, the most diversified district in our sample, exhibit the worst irrigation and infrastructure conditions. The selected villages in Hasnabad, the most diversified among all the villages, are placed in the worst condition with regard to irrigation, suffer from high salinity of the underground water and depend mainly on rainwater; these villages are also very backward in terms of infrastructure. Consequently, farmers here are subject to high levels of vulnerability.

${ }^{10}$ Details of coding are given in Appendix 3. 
The selected villages in Bongaon, the second most diversified villages, are placed in the second worst condition with regard to irrigation, suffer from weather-related risk and uncertainty, though to a lesser extent compared to Hasnabad, even though they are almost as diversified as Hasnabad. Placed in the second worst condition with regard to infrastructure (after the village in Golsi), Bongaon allocates the highest proportion of land to vegetables. These two areas, thus, represent the cases where acute shortages of irrigation and infrastructure induce farmers to adopt diversification just as a survival strategy, to avoid the chance of falling into extreme poverty and crisis, even in the absence of good infrastructure.

\subsubsection{Determinants of Crop Diversification: The Role of Irrigation, Farm Size and Family Labour}

Table 7.2 shows that the more diversified villages have higher proportions of marginal and very marginal farmers, and a lower average farm size compared to the less diversified villages. Further, average family labour days used per hectare of land and proportions of family labour in total labour days used (Table 7.3) are higher for both traditional and high-value crops, with vegetables showing a much greater dependence on family labour in the more diversified villages. Villages in Hasnabad and Bongaon, the worst affected with acute shortage of irrigation and infrastructure, diversify their cropping system to the highest extent depending mainly on family labour. Balagar, with its dependence on private sources of irrigation and relatively good infrastructure, also diversifies to a great extent.

Table 7.2 Farm size and family labour days with CDI

\begin{tabular}{l|l|l|l|l|l|l|l}
\hline \multicolumn{2}{|c|}{} & \multicolumn{3}{|l|}{ Less diversified blocks } & \multicolumn{3}{l}{ More diversified blocks } \\
\cline { 3 - 8 } & $\begin{array}{l}\text { Memari } \\
(\%)\end{array}$ & $\begin{array}{l}\text { Pandua } \\
(\%)\end{array}$ & $\begin{array}{l}\text { Galsi } \\
(\%)\end{array}$ & $\begin{array}{l}\text { Balagarh } \\
(\%)\end{array}$ & $\begin{array}{l}\text { Bonga } \\
(\%)\end{array}$ & $\begin{array}{l}\text { Hasnabad } \\
(\%)\end{array}$ \\
\hline $\begin{array}{l}\text { Proportion } \\
\text { of farming } \\
\text { household }\end{array}$ & Farm size & 30.89 & 27.42 & 30.91 & 39.06 & 41.88 & 45.45 \\
\cline { 2 - 8 } & $0<0.5(\mathrm{ha})$ & & & & & & \\
\hline Average farm size & 61.56 & 67.47 & 63.64 & 84.37 & 74.71 & 68.28 \\
\hline $\begin{array}{l}\text { Average family labour } \\
\text { days per hectare }\end{array}$ & 0.98 & 0.86 & 1.01 & 0.69 & 0.79 & 0.83 \\
\hline CDI & 134.82 & 138.33 & 45.38 & 252.68 & 179.48 & 236.59 \\
\hline
\end{tabular}

Table 7.3 Percentage of labour days provided by the family members in total labour days

\begin{tabular}{l|l|l|l|l|l|l}
\hline \multirow{2}{*}{ Crops } & \multicolumn{3}{|l|}{ Less diversified blocks } & More diversified blocks & \\
\cline { 2 - 7 } & Memari & Pandua & Galsi & Balagarh & Bonga & Hasnabad \\
\hline Aus and Aman & 36.66 & 19.64 & 2.55 & 36.83 & 33.62 & 39.42 \\
\hline Boro & 22.23 & 29.99 & 8.59 & 32.13 & 26.64 & 50.69 \\
\hline Vegetables & 8.69 & 19.62 & 54.68 & 65.89 & 54.08 & 85.61 \\
\hline
\end{tabular}


Table 7.4 Results of Tobit regression with crop diversification index (CDI) as the dependent variable with all 360 households

\begin{tabular}{|c|c|c|c|c|c|c|c|c|c|c|}
\hline & Intercept & $\begin{array}{l}\text { Family } \\
\text { labour }\end{array}$ & Farm size & Irri area & Fertili/hec & $\mathrm{D}_{1 \mathrm{Bal}}$ & $\mathrm{D}_{2 \mathrm{Bon}}$ & $\mathrm{D}_{3 \text { Hasna }}$ & $\mathrm{D}_{\text {4galsi }}$ & $\mathrm{D}_{5 \mathrm{Mem}}$ \\
\hline $\begin{array}{l}\text { Coefficient } \\
\text { value }\end{array}$ & $\begin{array}{l}0.373 \\
(17.27)\end{array}$ & $\begin{array}{l}0.00011 \\
(3.29)\end{array}$ & $\begin{array}{l}-0.038 \\
(-2.17)\end{array}$ & $\begin{array}{l}0.024 \\
(2.45)\end{array}$ & $\begin{array}{l}6.03791 \mathrm{e}-07 \\
(0.37)\end{array}$ & $\begin{array}{l}0.35 \\
(14.45)\end{array}$ & $\begin{array}{l}0.34 \\
(13.65)\end{array}$ & $\begin{array}{l}0.35 \\
(12.62)\end{array}$ & $\begin{array}{l}0.27 \\
(10.54)\end{array}$ & $\begin{array}{l}0.26 \\
(10.24)\end{array}$ \\
\hline
\end{tabular}

To recheck the validity of the conclusions, we estimate the overall impact of family labour, farm size, extent of irrigation and use of fertilizers on crop diversification across different regions of our sample. We run a Tobit regression with $\mathrm{CDI}^{11}$ (lying between 0 and 1) as the dependent variable with 360 farm households and five area dummies to represent six irrigation-infrastructure types, the intercept representing the benchmark value of the least diversified region (Pandua). The result shows (Table 7.4) that use of family labour has a strong positive association and farm size has a strong inverse association with crop diversification, confirming our hypotheses and supporting the observations already made in the literature that crop diversification is more confined to smaller sized farms. The result on family labour strengthens the argument that smaller sized farms find advantage in producing labour-intensive high-value crops with the use of family labour to a large extent. The strong positive relation between the extent of irrigation and crop diversification, however, does not tell us anything about the importance of the pattern of irrigation. It does not help us to examine the validity of the argument that availability of publicly supplied cheap irrigation leads to specialization in water-intensive traditional crops and increasing access to costly irrigation developed through private investment induces crop diversification. This specific hypothesis is supported by the result that the coefficient of dummies shows significant positive difference in the crop diversification index from the benchmark value of Pandua represented by the coefficient of the intercept which also is significant. This shows that, other things remaining the same, the extent of crop diversification increases significantly over different infrastructure levels and irrigation types compared to the lowest index of Pandua, the most advanced village with regard to irrigation and infrastructure.

\subsubsection{The Relationship Between the Extent of Crop Diversification and Pattern of Consumption, Poverty and Malnutrition Among Farmers Belonging to Different Size Classes}

Based on primary data on value of output and cost of production of different crops pertaining to the selected villages in the three districts, we estimate the net per

\footnotetext{
11 We use CDI as the dependent variable, whose value lies between 0 and 1 (see the methodology). Since the range of value of CDI is censored, OLS estimation may produce biased estimates. The Tobit regression model is more appropriate in this case.
} 
Table 7.5 Net per capita earnings of the farming households from the production of cereals potato and vegetables (Rs. at current prices) and crop diversification indices

\begin{tabular}{l|l|l|l|l|l|l}
\hline $\begin{array}{l}\text { Farm size } \\
\text { in hectare }\end{array}$ & $\begin{array}{l}\text { Memari } \\
(\mathrm{CDI})\end{array}$ & $\begin{array}{l}\text { Galsi } \\
(\mathrm{CDI})\end{array}$ & $\begin{array}{l}\text { Pandua } \\
(\mathrm{CDI})\end{array}$ & $\begin{array}{l}\text { Balagarh } \\
(\mathrm{CDI})\end{array}$ & $\begin{array}{l}\text { Bonga } \\
(\mathrm{CDI})\end{array}$ & $\begin{array}{l}\text { Hasnabad } \\
(\mathrm{CDI})\end{array}$ \\
\hline $0<0.5$ & $\begin{array}{l}2325.20 \\
(0.48)\end{array}$ & $\begin{array}{l}1,541.23 \\
(0.55)\end{array}$ & $\begin{array}{l}3,742.59 \\
(0.44)\end{array}$ & $\begin{array}{l}2,080.83 \\
(0.65)\end{array}$ & $\begin{array}{l}1,458.20 \\
(0.60)\end{array}$ & $\begin{array}{l}1,253.45 \\
(0.73)\end{array}$ \\
\hline $0.5<1$ & $\begin{array}{l}3,802.66 \\
(0.51)\end{array}$ & $\begin{array}{l}4,565.64 \\
(0.55)\end{array}$ & $\begin{array}{l}5,731.87 \\
(0.43)\end{array}$ & $\begin{array}{l}3,819.91 \\
(0.67)\end{array}$ & $\begin{array}{l}3,352.72 \\
(0.72)\end{array}$ & $\begin{array}{l}1,206.26 \\
(0.69)\end{array}$ \\
\hline $1<2$ & $\begin{array}{l}5,404.41 \\
(0.46)\end{array}$ & $\begin{array}{l}5,121.49 \\
(0.57)\end{array}$ & $\begin{array}{l}7,462.01 \\
(0.48)\end{array}$ & $\begin{array}{l}5,120.80 \\
(0.54)\end{array}$ & $\begin{array}{l}1,156.57 \\
(0.73)\end{array}$ & $\begin{array}{l}2,940.12 \\
(0.55)\end{array}$ \\
\hline $2<4$ & $\begin{array}{l}5,623.36 \\
(0.55)\end{array}$ & $\begin{array}{l}9,131.40 \\
(0.57)\end{array}$ & $\begin{array}{l}5,267.69 \\
(0.44)\end{array}$ & $\begin{array}{l}2,636.63 \\
(0.52)\end{array}$ & $\begin{array}{l}809.71 \\
(0.72)\end{array}$ & $\begin{array}{l}4,270.39 \\
(0.64)\end{array}$ \\
\hline Average & $\begin{array}{l}4,010.77 \\
(0.49)\end{array}$ & $\begin{array}{l}4,489.11 \\
(0.55)\end{array}$ & $\begin{array}{l}5,841.18 \\
(0.45)\end{array}$ & $\begin{array}{l}3,227.40 \\
(0.64)\end{array}$ & $\begin{array}{l}1,949.54 \\
(0.67)\end{array}$ & $1,960.79$ \\
& 28.33 & 95.26 & 172.94 & 120.23 & 139.42 \\
\hline $\begin{array}{l}\text { Labour } \\
\text { days per } \\
\text { family } \\
\text { member } \\
\begin{array}{l}\text { engaged in } \\
\text { cultivation }\end{array}\end{array}$ & 57.74 & & & & & \\
\hline
\end{tabular}

Crop diversification indices are in parentheses

capita earning of the farming households derived from the cultivation of major food crops, cereals, potato and vegetables, which are shown in Table 7.5 along with crop diversification indices. It is seen that per capita earning from cultivation of cereals, potato and vegetables is extremely low, particularly in more diversified rain-fed areas-it is very low compared to the less diversified areas and much lower than the poverty-level income. It is also seen that very marginal and marginal farmers $(<0.5 \mathrm{~h}$, and 0.5 to $<1 \mathrm{~h})$ with higher crop diversification indices in the most diversified areas suffer from a huge shortfall of earning from the poverty line income from cultivation of food crops. The big shortfall of earning from the poverty line income across the classes, particularly in the rain-fed regions, leads to greater diversification. Apart from vegetables, the farmers are likely to produce fruits, oilseeds, jute and fibres to a much larger extent, compared to the districts endowed with much greater irrigation facilities, in order to meet their cash needs. ${ }^{12}$

We conduct an analysis of variance for per capita earning across size classes and over regions. It is seen that while variations both among size classes and among regions are statistically significant, the degree of variation across regions is stronger $(F=4.04, P=0.02)$ than the variation across size classes $(F=3.72$, $P=0.04$ ). This provides some factual ground in favour of the argument that lower the size of farm, the greater would be the need to earn supplementary income over and above the main income from production of food crops, and this need is stronger in rain-fed regions.

12 In some cases (Table 7.5), larger farmers are found to have lower earning per capita compared to smaller farmers, which may be due to the fact that they depend more on other non-food crops. 
Table 7.6 Average per capita per day consumption (in $\mathrm{kg}$ )

\begin{tabular}{l|l|l|l|l|l}
\hline Blocks name & Cereal & Pulses & Vegetables & Potato & Fish and chicken \\
\hline Memari & 0.56 & 0.03 & 0.13 & 0.12 & 0.03 \\
\hline Galsi & 0.56 & 0.03 & 0.37 & 0.28 & 0.06 \\
\hline Pandua & 0.58 & 0.02 & 0.18 & 0.40 & 0.10 \\
\hline Balagarh & 0.57 & 0.03 & 0.17 & 0.21 & 0.04 \\
\hline Hasnabad & 0.43 & 0.03 & 0.31 & 0.18 & 0.03 \\
\hline Bonga & 0.57 & 0.03 & 0.13 & 0.14 & 0.04 \\
\hline
\end{tabular}

Further, it is observed that in villages undertaking cultivation of high-value crops to a larger extent (all the more diversified villages), labour days per family member engaged in cultivation are considerably higher compared to the less diversified villages, i.e. on an average, a farmer in the more diversified villages puts in much more labour compared to a farmer in the less diversified villages for bare subsistence (the last row of Table 7.5).

A comparative analysis of earnings from cultivation of cereals, potato and vegetables gives us a very partial idea regarding the comparative well-being of the households since we have not included income from oil seeds and jute in the analysis. We conduct a direct estimation of per capita consumption of different items of consumption to arrive at a comparative analysis with regard to poverty.

As Table 7.6 shows, consumption of cereal does not show any systematic pattern across blocks. However, the least diversified village in Pandua, with the highest level of total income from cultivation of food crops among the survey villages, also enjoys the highest level of consumption of cereal and potato. The most diversified Hasnabad, which suffers most from an acute problem with regard to irrigation and high salinity of soil, has a very low per capita earning from food crops and consumes a meagre quantity of cereal per capita. Though it supplements the consumption of cereal with a higher quantity of vegetables compared to most of the survey villages, its overall consumption level remains very low. However, the other two more diversified villages, namely, Balagar and Bongaon have a relatively high level of consumption of cereals and high-value crops not only compared to Hasnabad but also Memari, the other mono crop area in the sample with substantially higher earnings from food crops. It appears that income levels of more diversified areas would increase substantially to almost reach the levels of less diversified areas in our sample if income from cultivation of other crops, namely jute, fruits, oil seeds and fibre crops are included in the estimation of income from cultivation. Except the area under most adverse natural conditions (Hasnabad), all the more diversified areas have been able to surpass the consumption level of Memari, a mono crop region enjoying irrigation and infrastructure advantage.

We estimate the amount of intake of different nutrients ${ }^{13}$ by the sample farmers belonging to different size classes of agricultural holdings for each of the

13 Estimation of consumption of different nutrients are based on conversion rates obtained from Appendix B of NSSO Report No. 471 (55/1.0/9). 
Table 7.7 Average per capita consumption of fat, protein and calorie ${ }^{a}$ with crop diversification indices

\begin{tabular}{l|l|l|l|l|l|l}
\hline \multirow{4}{*}{} & \multicolumn{3}{|l|}{ Less diversified blocks } & More diversified blocks & \\
\cline { 2 - 7 } & Memari & Pandua & Galsi & Balagarh & Bonga & Hasnabad \\
\hline kcal & $2,247.44$ & $2,655.31$ & $2,535.99$ & $2,397.39$ & $2,313.10$ & $1,929.61$ \\
(CDI) & $(0.49)$ & $(0.45)$ & $(0.55)$ & $(0.64)$ & $(0.67)$ & $(0.68)$ \\
\hline Protein & 58.04 & 73.78 & 73.78 & 62.53 & 60.72 & 52.39 \\
\hline Fat & 4.87 & 7.43 & 7.43 & 5.33 & 5.26 & 4.74 \\
\hline
\end{tabular}

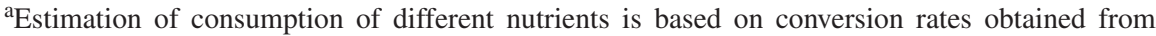
Appendix B of NSSO Report No. 471 (55/1.0/9)

villages separately. Table 7.7 shows, treating Memari as an outlier, there is a smooth downward trend in per capita intake of kilocalorie associated with a smooth upward trend with diversification indices across different areas. Again, among the six villages, only two can achieve the above poverty level average calorie intake. Among the less diversified villages enjoying relatively higher levels of income, Pandua and Golsi achieve higher than prescribed minimum levels of calorie and protein. The most diversified village in Hasnabad ends up with a very big shortfall from the prescribed minimum level of nutritional intake. The shortfall is much less for the other two diversified areas, namely Balagar and Bongaon. While Hasnabad farmers fail to overcome the negative impact of the irrigation and infrastructure disadvantage by diversifying the cropping pattern, the scope of achieving greater access to irrigation through private investment enables Balagar and Bongaon farmers to reach close to the prescribed minimum level of nutrition. The nutritional level achieved by Memari, on the other hand, remains much below the prescribed minimum level of nutrition, in spite of its irrigation and other advantages. This reconfirms the observation that by taking resort to more diversification towards production of fruits, jute, oilseeds and other fibre crops, all the more diversified regions except Hasnabad can increase the level of income and consumption to reach close to the prescribed minimum level of nutrition. While they achieve this condition by putting in the extremely hard labour of the family members, Hasnabad, the most diversified region of the sample, can maintain only some minimum level of nutrition, which is much below the prescribed minimum level, by putting in still harder labour of the family members.

The first row of Table 7.7 showing almost an inverse association between intake of kcal per capita and crop diversification indices (if Memari is treated as an outlier) seems to indicate that diversification towards high-value crop production is taken up by poor farming households as a survival strategy in places where lack of publicly supplied irrigation makes it impossible to survive on water-intensive traditional crops. 
Table 7.8 Efficiency measures

\begin{tabular}{l|l|l|l|l|l|l}
\hline \multirow{2}{*}{ Crops } & \multicolumn{3}{|l|}{ Less diversified blocks } & More diversified blocks & \\
\cline { 2 - 7 } & Memari & Pandua & Galsi & Balagarh & Bonga & Hasnabad \\
\hline Aus and Aman & 0.29 & 0.46 & 0.18 & 0.44 & 0.15 & 0.19 \\
\hline Boro & 0.45 & 0.58 & 0.53 & 0.72 & 0.54 & - \\
\hline Vegetables & - & - & 0.12 & 0.29 & 0.30 & 0.09 \\
\hline
\end{tabular}

\subsubsection{Viability of Crop Diversification: Impact of Crop Diversification on Farm Efficiency and Profitability}

We conducted an estimation ${ }^{14}$ of the overall efficiency score of the 360 households in the production of three crop varieties (Table 7.8). We get two contrasting pictures in Hasnabad and Balagar, the two more diversified places. Hasnabad, the most diversified place, suffering from acute irrigation problem and poverty, has a very low average efficiency score for vegetables, which is the lowest among all the places. By contrast, Balagar, another diversified place where access to irrigation is developed through private investment and efforts, contains more efficient farms in large numbers for both traditional crops and vegetables so that the average efficiency scores are high, compared to other places. Most of the inefficient farmers for cultivation of Aus and Aman rice are concentrated in Bongaon, Hasnabad and Golsi. While vegetables production, in general, is subject to inefficiency as compared to traditional crops, diversified regions, with the only exception of Balagar, are, in general, less efficient also in traditional crop production. This shows that farmers under extremely adverse conditions of production cannot maintain efficiency in input use even if they diversify their cropping pattern. Farmers can apply inputs relatively more efficiently only where they can overcome the difficulties by undertaking private investment. However, good infrastructure works as a necessary condition for achieving efficiency in the use of inputs in such cases. This leads us to conclude that poor farmers under adverse production conditions (Hasnabad and Bongaon) diversify their cropping pattern to avoid the condition of extreme destitution even if such diversification results in inefficient use of inputs.

To examine the role of crop diversification, among other factors, in influencing the relative efficiency of farms, Tobit regression with efficiency score as the dependent variable has been run (Table 7.9). It is seen that incurring excessive expenditure for irrigation is a general cause of inefficiency in the production of each of the crops considered. Apart from this, Aus and Aman production, in general, is subject to excessive expenditure incurred on other material inputs, fertilisers and pesticides; Boro is subject to excessive expenditure incurred on

${ }^{14}$ Using Efficiency Management System (EMS) Software developed by Holger Scheel of the University of Dormund, Germany. Tobit regression is run because the range of efficiency score obtained from the DEA model is censored. 
Table 7.9 Results of Tobit regression with efficiency score for 360 households for Aus and Aman, Boro, vegetables as dependent variable

\begin{tabular}{l|l|l|l}
\hline & Aus and Aman & Boro & Vegetables \\
\hline Constant & $0.5941539(9.45)$ & $0.8142483(11.35)$ & $0.3897623(2.50)$ \\
\hline Fertiliser & $-0.0000119(-2.82)$ & $-0.0000318(-4.21)$ & $1.68 \mathrm{e}-07(1.05)$ \\
\hline Pesticide & $-0.000037(-3.07)$ & $-1.13 \mathrm{e}-06(-0.08)$ & $-2.20 \mathrm{e}-07(-0.33)$ \\
\hline Seed & $1.37 \mathrm{e}-06(0.16)$ & $-9.63 \mathrm{e}-06(-1.17)$ & $-2.66 \mathrm{e}-06(-2.26)$ \\
\hline Water & $-0.0000222(-1.74)$ & $-0.0000207(-4.05)$ & $-5.23 \mathrm{e}-06(-3.08)$ \\
\hline Labour days & $-0.0000219(-0.83)$ & $-0.0001463(-2.08)$ & $-0.000024(-2.52)$ \\
\hline CDI & $-0.1498135(-1.51)$ & $0.220851(2.22)$ & $-0.196185(-1.17)$ \\
\hline Farm size & $0.0329643(1.80)$ & $-0.0459162(-1.98)$ & $0.0350221(1.06)$ \\
\hline Dummy Galsi & $-0.1706402(-2.95)$ & $0.0334298(0.52)$ & - \\
\hline Dummy Memari & $-0.087933(-1.59)$ & $-0.0920167(-1.28)$ & - \\
\hline Dummy Balagarh & $-0.003884(-0.07)$ & $0.0831096(1.51)$ & $0.1403117(1.71)$ \\
\hline
\end{tabular}

fertilisers and labour; vegetables are subject to excessive expenditure incurred on seed and labour. While large-sized farms are more efficient in the production of Aus and Aman, smaller farms are more efficient producers of Boro; farm size has no impact on efficiency of vegetable production. The degree of crop diversification has no significant impact on the efficiency of either traditional rice (Aus and Aman) or vegetables.

Diversification, in general, and high-value crop production, in particular, are not positively associated with the efficiency of crop production.

We estimate farm business income and profits from cultivation of traditional crops and high-value crops to examine further the viability of the strategy of crop diversification.

It is seen that (Table 7.10) farm business income from the production of traditional crops is higher for the less diversified traditional crop producing zones as compared to the more diversified zones. For vegetables, while two of the more diversified villages obtain considerably higher levels of farm business income as

Table 7.10 Farm business income and rate of profit

\begin{tabular}{|c|c|c|c|c|c|c|c|}
\hline & & \multicolumn{2}{|l|}{ Burdwan } & \multicolumn{2}{|l|}{ Hooghly } & \multicolumn{2}{|c|}{ North 24 Paragana } \\
\hline & & Memari & Galsi & Pandua & Balagarh & Bonga & Hasnabad \\
\hline \multirow[t]{3}{*}{$\begin{array}{l}\text { Farm business } \\
\text { income from }\end{array}$} & $\begin{array}{l}\text { Aus and } \\
\text { Aman }\end{array}$ & $29,436.10$ & $39,305.68$ & $28,337.86$ & $19,828.1$ & $20,489.30$ & $17,157.14$ \\
\hline & Boro & $34,819.98$ & $33,229.08$ & $23,660.19$ & $24,330.42$ & $23,350.50$ & $38,515.00$ \\
\hline & Vegetables & $20,524.14$ & $129,412.91$ & $-18,606.71$ & $29,449.02$ & $38,822.38$ & $-36,086.54$ \\
\hline \multirow{3}{*}{$\begin{array}{l}\text { Profit per unit } \\
\text { of investment } \\
\text { of }\end{array}$} & $\begin{array}{l}\text { Aus and } \\
\text { Aman }\end{array}$ & 1.41 & 0.25 & 0.77 & 1.08 & 0.96 & 2.02 \\
\hline & Boro & 1.95 & 1.58 & 0.80 & 0.82 & 0.98 & 4.35 \\
\hline & Vegetables & 1.39 & 0.33 & 1.24 & 0.71 & 0.37 & 0.35 \\
\hline \multicolumn{2}{|c|}{ Per capita net earning } & $4,010.77$ & $4,489.11$ & $5,841.18$ & $3,227.40$ & $1,949.54$ & $1,960.79$ \\
\hline
\end{tabular}


compared to the less diversified ones, the village in Hasnabad, the most diversified village with a relatively high proportion of land under vegetables, obtains a negative level of farm business income from vegetable production. This seems quite understandable when we consider the fact that in Hasnabad, the imputed value of family labour is too high. We estimate profit per unit of investment (taking into account actual cost incurred and actual value of output received by the farmers) to get an idea about actual returns. It is seen that Memari, with its assured supply of water and comparatively developed infrastructure, earns a comparatively higher rate of profit not only for traditional crops but also for vegetables. While vegetable-producing villages earn high rates of profit for Aus and Aman rice, the rate of profit from vegetable production in these most diversified vegetable-producing villages is not only very low but also lower than the two least diversified villages falling under Pandua and Memary. However, the less diversified Golsi [with higher CDI (0.55) compared to Pandua and Memary] has the lowest profit rate for vegetables. In fact, what seems to emerge from the observations is that higher profit rates from vegetable production is not associated with diversification in favour of vegetables in vegetable-producing areas. Not only does a one rupee expenditure on cultivation gives less returns in the case of vegetables as compared to other crops in more diversified areas but it also gives less returns as compared to vegetables in less diversified areas. Among the three more diversified villages, Balagar is most advanced in infrastructure, which ensures its farmers a higher average price for their product, compared to other villages within the 'more diversified' group. Bongaon has a much lower rate of profit (0.37) compared to Balagar (0.71) due to its extremely backward infrastructure. The two less diversified villages, Memary and Pandua, endowed with not only good irrigation facilities but also the best infrastructure among the survey villages, end up with the highest rates of profit.

Coming to aggregate per capita net earnings from cultivation, we see that it is higher for all the less diversified villages compared to any of the more diversified ones. Farmers in the more diversified villages end up with considerably less income compared to farmers in the less diversified villages.

\subsection{Concluding Observations and Policy Implications}

Increasing diversification is associated with falling average size of farms and deteriorating access to public irrigation across the survey areas. This gives rise to almost an inverse association between crop diversification indices, on the one hand, and per capita intake of kilocalorie (Table 7.7), on the other. While the small and marginal farmers practise diversification and production of high-value crops in greater proportion, under extremely adverse soil and water conditions, they find it very hard to avoid extreme poverty and malnutrition by taking resort to diversification. In such cases, high-value crop production is particularly associated with inefficiency, low profit and negative farm business income. The other case of diversification is where farmers become capable of averting risk only by 
undertaking investment for development of access to irrigation. In such cases, diversification and high-value crop production are induced by the motivation of increasing income only in the presence of good infrastructure, resulting in relative efficiency and profitability. In such cases, farmers can increase their income and consumption level to reach close to the minimum specified level of nutrition. In both cases, farmers have to put in a huge amount of labour of the family members to maintain a certain minimum level of income and avoid the situation of extreme poverty and vulnerability.

Effectiveness of diversification as a strategy for reducing rural poverty depends, to a great extent, on the presence of good infrastructure with better linkages with markets (Appendix 3), which can ensure remunerative product prices as well as farmers' access to an improved variety of inputs at reasonable prices. Direct policy intervention is needed for improving rural infrastructure, increasing access to institutional credit and promoting research and innovation in the field of development of low-cost plant nutrients, rainwater conservation, surface irrigation development and soil science.

\section{Appendix 1}

\section{Sample Design:}

A three-stage stratified random sampling procedure has been followed to construct the sample through the following: first, selection of administrative blocks; second, selection of villages, with the help of basic information and data from the BDO and Revenue Inspectors' Office, so as to represent the required variation in infrastructure and irrigation in both cases; finally, selection of households belonging to different size classes.

\begin{tabular}{l|l|l|l}
\hline District & Block & Gram Panchayat & Village (no. of farms) \\
\hline \multirow{2}{*}{ Burdwan } & Memari & Gope-gantar 1 & Sankarpur (60) \\
\cline { 2 - 4 } & Golsi & Bhuri & Jujuti, Ketna (60) \\
\hline \multirow{2}{*}{ Hooghly } & Pandua & Berela-Konchmali & Boragori (60) \\
\cline { 2 - 4 } & Balagarh & Somra 1 & Paigachhi, Abdulpur, Natagarh (60) \\
\hline \multirow{2}{*}{ North 24 Parganas } & Bongaon & Chouberia & Gopinathpur (60) \\
\cline { 2 - 4 } & Hasnabad & Amlani & Haripur (60) \\
\hline
\end{tabular}

\section{Appendix 2}

DEA is a linear programming technique for constructing a non-parametric piecewise linear envelop to a set of observed output and input data. Efficiency is defined as a measure of how efficiently inputs are employed to produce a given level of 
output. The score of the most efficient farms being one, with minimum level of inputs applied to a given level of output, the score of each farm will lie between zero and one.

Overall technical efficiency (OTE) of the $i$ th farm is obtained from following input-oriented DEA model.

$$
\min _{\theta_{i}^{\mathrm{CRS}}, \lambda,} \theta_{i}^{\mathrm{CRS}}
$$

Subject to

$$
\begin{aligned}
& -y_{i}+Y \lambda \geq 0, \\
& \theta_{i}^{\mathrm{CRS}} x_{i}-X \lambda \geq 0, \\
& \lambda \geq 0
\end{aligned}
$$

where $\theta_{i}^{\mathrm{CRS}}$ is a OTE measure of the $i$ th farm under CRS, $X$ is a $n \times r$ input matrix with columns $x_{i}, Y$ is $m \times r$ output matrix with columns $y_{i}$, and $\lambda$ is a $r \times 1$ vector, where $r$ is the number of farms. The problem has to be solved $r$ times to get $r$ farmers' efficiency score, which is evaluated under different sets of observations as envelope. The imposition of constraint on the intensity vector $\lambda$ guarantees that $\theta_{i}^{\text {CRS }}$ lies between zero and one. The CRS linear programming problem can be modified to account for VRS by incorporating the convexity constraint.

\section{Appendix 3}

Code for pattern of irrigation

\begin{tabular}{l|l}
\hline Pattern & Code \\
\hline Public irrigation system with canal and deep tube well along with all other types & 1 \\
\hline $\begin{array}{l}\text { No canal, no deep tube well, but availability of enough surface water due to } \\
\text { proximity to river }\end{array}$ & 2 \\
\hline No canal, no deep tube well, only shallow tube well, tank, etc. & 3 \\
\hline $\begin{array}{l}\text { No canal, no deep tube well, and use of underground water is not always possible } \\
\text { in sufficient quantity due to high salinity }\end{array}$ & $2 \times 3=6^{\mathrm{a}}$ \\
\hline
\end{tabular}

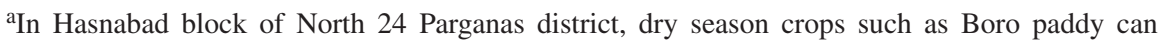
hardly be produced without incurring excessive expenditure on irrigation; the level of productivity remains very low for other crops due to high salinity. This negative impact of the absence of a public irrigation system is highly intensified, and hence, we have multiplied the code 2 by 3 in order to catch this irrigational disadvantage 


\begin{tabular}{|c|c|c|c|c|}
\hline District & Block & Gram Panchayat & Village & Code for type of irrigation \\
\hline Burdwan & Memari & Gope-gantar 1 & Sankarpur & $\begin{array}{l}\text { Canal, deep tube well and others } \\
\text { (shallow tube well, tank and river } \\
\text { lift): Code } 1\end{array}$ \\
\hline Burdwan & Golsi & Bhuri & Jujuti, Ketna & $\begin{array}{l}\text { No canal, no deep tube well, but } \\
\text { availability of enough surface } \\
\text { water due to proximity to river: } \\
\text { Code } 2\end{array}$ \\
\hline Hooghly & Pandua & Berela-Konchmali & Boragori & $\begin{array}{l}\text { Canal, deep tube well and others } \\
\text { (shallow tube well, tank and river } \\
\text { lift): Code } 1\end{array}$ \\
\hline Hooghly & Balagarh & Somra 1 & $\begin{array}{l}\text { Paigachhi, } \\
\text { Abdulpur, } \\
\text { Natagarh }\end{array}$ & $\begin{array}{l}\text { No canal, no deep tube well, but } \\
\text { availability of enough surface } \\
\text { water due to proximity to river: } \\
\text { Code } 2\end{array}$ \\
\hline $\begin{array}{l}\text { North } 24 \\
\text { Parganas }\end{array}$ & Bongaon & Chouberia & Gopinathpur & $\begin{array}{l}\text { No canal, no deep tube well, only } \\
\text { shallow tube well, tank, etc.: } \\
\text { Code } 3\end{array}$ \\
\hline $\begin{array}{l}\text { North } 24 \\
\text { Parganas }\end{array}$ & Hasnabad & Amlani & Haripur & $\begin{array}{l}\text { No canal, no deep tube well and } \\
\text { high salinity: Code } 6^{\mathrm{a}}\end{array}$ \\
\hline \multicolumn{5}{|c|}{ Refer to last table for codification } \\
\hline \multicolumn{5}{|c|}{ Code for distance and road type } \\
\hline \multicolumn{3}{|c|}{ Distance Code } & \multicolumn{2}{|c|}{ Code for type of road } \\
\hline \multicolumn{3}{|c|}{$\begin{array}{l}0 \text { to }<5 \mathrm{~km}: 1 \\
5 \text { to }<10 \mathrm{~km}: 2 \\
10 \text { to }<15 \mathrm{~km}: 3 \\
15 \text { and above: } 4\end{array}$} & \multicolumn{2}{|c|}{$\begin{array}{l}\text { Metal road: } 1 \\
\text { Mud road: } 2 \\
\text { No road: } 3\end{array}$} \\
\hline
\end{tabular}

\begin{tabular}{l|l|l|l|l|l|l|l|l}
\hline Codification of survey villages for infrastructure \\
\hline & \begin{tabular}{l} 
Distance from \\
Village \\
\hline storage
\end{tabular} & $\begin{array}{l}\text { Road } \\
\text { type } \\
\text { connect- } \\
\text { ing cold } \\
\text { storage }\end{array}$ & Market & $\begin{array}{l}\text { Road } \\
\text { type } \\
\text { con- } \\
\text { necting } \\
\text { market }\end{array}$ & $\begin{array}{l}\text { High } \\
\text { way }\end{array}$ & $\begin{array}{l}\text { Road } \\
\text { type } \\
\text { connect- } \\
\text { ing high } \\
\text { way }\end{array}$ & $\begin{array}{l}\text { Rail } \\
\text { station }\end{array}$ & $\begin{array}{l}\text { Road type } \\
\text { connecting } \\
\text { rail station }\end{array}$ \\
\hline Sankarpur & $4 \mathrm{~km}$ & Metal & $1 \mathrm{~km}$ & Mud & $10 \mathrm{~km}$ & Metal & $6 \mathrm{~km}$ & Metal \\
\hline Code & 1 & 1 & 1 & 2 & 3 & 1 & 2 & 1 \\
\hline Jujuti, Ketna & $10 \mathrm{~km}$ & Mud & $8 \mathrm{~km}$ & Mud & $8 \mathrm{~km}$ & Mud & $14 \mathrm{~km}$ & Mud \\
\hline Code & 3 & 2 & 2 & 2 & 2 & 2 & 3 & 2 \\
\hline Boragori & $1 \mathrm{~km}$ & Metal & $1.5 \mathrm{~km}$ & Metal & $0.5 \mathrm{~km}$ & Mud & $1.5 \mathrm{~km}$ & Metal \\
\hline Code & 1 & 1 & 1 & 1 & 1 & 2 & 1 & 1 \\
\hline $\begin{array}{l}\text { Paigachhi, } \\
\text { Abdulpur, } \\
\text { Natagarh }\end{array}$ & $4.5 \mathrm{~km}$ & Mud & $3 \mathrm{~km}$ & Mud & $1 \mathrm{~km}$ & Mud & $3 \mathrm{~km}$ & Mud \\
\hline Code & 1 & 2 & 1 & 2 & 1 & 2 & 1 & 2 \\
\hline Gopinathpur & $7 \mathrm{~km}$ & Mud & $3 \mathrm{~km}$ & Mud & $7 \mathrm{~km}$ & Mud & $25 \mathrm{~km}$ & Mud \\
\hline Code & 2 & 2 & 1 & 2 & 2 & 2 & 4 & 2 \\
\hline Haripur & $25 \mathrm{~km}$ & Mud & $3 \mathrm{~km}$ & Metal & $0.5 \mathrm{~km}$ & Metal & $1 \mathrm{~km}$ & Mud \\
\hline Code & 4 & 2 & 1 & 1 & 1 & 1 & 1 & 2 \\
\hline
\end{tabular}


Open Access This chapter is distributed under the terms of the Creative Commons Attribution Noncommercial License, which permits any noncommercial use, distribution, and reproduction in any medium, provided the original author(s) and source are credited.

\section{References}

Deaton A, Dreze J (2009) Food and nutrition in India: facts and interpretations. Econ Polit Wkly 44(07):42-65

Deaton A, Dreze J (2010) Poverty and calorie fundamental: response to Utsa Patnaik, vol 45(14), pp 78-80, 3 April

Desai BM, D'souza M, Sharma T (2011) Agricultural policy strategy instruments and implementations: a review and road ahead. Econ Polit Wkly 56(53):42-50

Gangapadhyay K, Sing K (2013) Extent of poverty in India: a different dimension. Econ Polit Wkly 48(5):75-79

Gulati A, Batila S (2001) Capital formation in Indian agriculture. Econ Polit Wkly 36(20):1697-1708

Himangsu (2008) What are these new poverty estimates and what do they imply. Econ Polit Wkly 43(43):38-43

Joshi PK, Gulati A, Birthal SP, Tewri L (2004) Agricultural diversification in South Asia: patterns determinants and policy implication. Econ Polit Wkly 39(24):2457-2467

Kumar T, Holla J, Guha P (2008) Engel curve method for measuring poverty. Econ Polit Wkly 43(30):115-123

Patnaik U (2010) A critical look at some proposition on consumption and poverty. Econ Polit Wkly 45(06):74-80

Rajuladevi AK (2001) Food poverty and consumption among landless labour households. Econ Polit Wkly 36(08):2656-2664

Rao CHH (2000) Decline in demand for foodgrains. Econ Polit Wkly 35(04):201-206

Rao PP, Birthal PS, Joshi PK (2006) Diversification towards high value agriculture. Econ Polit Wkly 41(36):2747-2753

Raphelle B (2013) Understanding the mismatch among three definitions of poverty. Econ Polit Wkly 48(01):51-59

Sing S (2004) Crisis and diversification in Punjab agriculture. Econ Polit Wkly 39(52):5583-5589

Singh J, Sidhu RS (2004) Factors in declining crop diversification. Econ Polit Wkly 39(52):5607-5610

Subramanian S (2008) Global poverty, inequality, and aid flows: a rough guide to some simple justice. Econ Polit Wkly 43(46):53-63

World Bank (2005) India: re-energizing the agricultural sector to sustain growth and reduce poverty. Oxford University Press, Oxford

World Bank (2010) India—new global poverty estimates, poverty in India, Wikipedia 